\title{
Video Tutorial Model Permainan dalam PJOK untuk Mendukung Pembelajaran Tematik Tema 3 Kegiatanku
}

\author{
I Gede Agus Darsana ${ }^{1 *}$, I Made Satyawan², Ni Luh Putu Spyanawati³, I Ketut Budaya \\ Astra $^{4}$, Kadek Yogi Parta Lesmana ${ }^{5}$
}

1,2,3,4,5 Pendidikan Olahraga, Universitas Pendidikan Ganesha, Singaraja, Indonesia

\section{ART ICLE INFO}

\section{Article history:}

Received June 10, 2021

Revised June 12, 2021

Accepted September 19, 2021

Available online October 25, 2021

Kata Kunci:

Video permainan, PJOK,

pembelajaran tematik.

\section{Keywords:}

Video games, PJOK, thematic learning

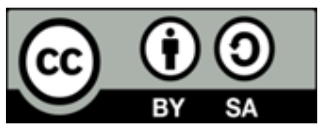

This is an open access article under the CC BY-SA license.

Copyright (C) 2021 by Author. Published by Universitas Pendidikan Ganesha.

\begin{abstract}
A B S T R A K
Tenaga pendidik mengalami kesulitan dalam menemukan materi yang sesuai dengan materi PJOK, kekurangan sumber berupa media video permainan PJOK yang sesuai dengan mata pelajaran lainnya. Penelitian ini bertujuan untuk mengembangkan video tutorial model permainan dalam PJOK untuk mendukung pembelajaran tematik. Penelitian pengembangan ini menggunakan model ADDIE, yaitu: Analisis, Desain, Pengembangan, Implementasi dan Evaluasi. Analisis data menggunakan analisis deskriptif kualitatif dan analisis deskriptif kuantitatif. Produk yang dikembangkan dalam penelitian ini adalah video tutorial yang berisi materi tentang pengertian, tujuan, sarana. Metode pengumpulan data dalam penelitian ini menggunakan metode angket atau kuisioner dalam bentuk skala skor.. Metode analisis data yang digunakan dalam penelitian ini yaitu analisis statistik kualitatif dan kuantitatif. Berdasarkan analisis data dan pembahasan didapatkan hasil yaitu ahli isi materi mata pelajaran menyatakan bahwa video tutorial model permainan dalam PJOK untuk mendukung pembelajaran tematik pada kelas 1 sekolah dasar tema 3 kegiatanku memiliki kualifikasi sangat baik. Penilaian ahli media pembelajaran memperoleh kualifikasi sangat baik. Penilaian ahli desain pembelajaran memperoleh kualifikasi sangat baik, dan penilaian praktisi lapangan memperoleh kualifikasi sangat baik. Jadi dapat disimpulkan hasil evaluasi dari keempat ahli di atas bahwa video tutorial model permainan PJOK layak atau valid. Disarankan agar guru-guru PJOK dapat memanfaatkan media ini untuk proses pembelajaran.
\end{abstract}

\section{A B S T RAK}

Educators have difficulty finding material that is suitable for PJOK material, lack of sources in the form of PJOK video game media that is suitable for other subjects. This study aims to develop video tutorials on game models in PJOK to support thematic learning. This development research uses the ADDIE model, namely: Analysis, Design, Development, Implementation and Evaluation. Data analysis used descriptive qualitative analysis and quantitative descriptive analysis. The product developed in this research is a video tutorial that contains material about the meaning, purpose, means. The data collection method in this study used a questionnaire or questionnaire in the form of a score scale. The data analysis method used in this study was qualitative and quantitative statistical analysis. Based on data analysis and discussion, it was found that the subject matter content expert stated that the video tutorial game model in PJOK to support thematic learning in grade 1 elementary school theme $3 \mathrm{My}$ activities had very good qualifications. Assessment of learning media experts obtained very good qualifications. The assessment of the learning design expert obtained a very good qualification, and the assessment of the field practitioner obtained a very good qualification. So it can be concluded from the evaluation results from the four experts above that the PJOK game model video tutorial is feasible or valid. It is recommended that PJOK teachers can use this media for the learning process.

\section{PENDAHULUAN}

Pendidikan merupakan usaha sadar dan terencana yang dilakukan manusia guna mengembangkan potensi yang dimilikinya agar mampu mencapai kehidupan yang lebih baik (Nada, I., Utaminingsih, S., \& Ardianti, 2018; Setiawan \& Rahmat, 2018). Pendidikan memiliki peranan penting 
dalam meningkatkan kualitas sumber daya manusia (Cintamulya, 2015; Suprianingsih \& Wulandari, 2020). Pendidikan merupakan proses perubahan atas hasil belajar yang didapat yang mencakup segala aspek kehidupan untuk tercapainya suatu tujuan tertentu yang diinginkan (Pane \& Dasopang, 2017). Pendidikan memegang peran penting dalam kehidupan peserta didik dan pendidikan diharapkan mampu membimbing peserta didik itu sendiri agar bisa lebih baik dan bermartabat. Untuk mewujudkan tujuan pendidikan, pembelajaran haruslah dijalankan melalui kegiatan belajar mengajar yang berkualitas (Fadillah \& Bilda, 2019). Pembelajaran yang baik adalah pembelajaran yang mampu meningkatkan minat serta kreativitas peserta didik (Gurung, 2020; Henriksen, Richardson, \& Shack, 2020; Idris \& Sida, 2019).

Jenjang pendidikan pada sekolah dasar sudah diterapkan kurikulum 2013 yang telah menerapakan pembelajaran tematik. Pembelajaran tematik atau pembelajaran terpadu adalah konsep pembelajaran yang terkait dengan beberapa mata pelajaran yang bertujuan untuk memberikan pengalaman pada peserta didik (Hidayah, Pgmi, Tarbiyah, \& Keguruan, 2015; Suadnyana, Wiyasa, Ardana, Putra, \& Wulandari, 2017). Salah satu mata pelajaran yang diajarkan di sekolah dasar adalah pendidikan jasmani olahraga dan kesehatan (PJOK). Pendidikan jasmani olahraga dan kesehatan merupakan suatu proses pembelajaran yang telah direncanakan secara sistematik bertujuan untuk meningkatkan atau mengembangkan individu baik secara kognitif, perseptual dan emosional (Haris, 2018; Pambudi, Winarno, \& Dwiyogo, 2019; Spyanawati \& Lesmana, 2016). Selain itu PJOK sangat memiliki pengaruh yang baik untuk pola hidup sehat dengan melakukan gerakan-gerakan tertentu untuk pertumbuhan fisik dan pisikis secara seimbang (Raibowo \& Nopiyanto, 2020; Satyawan, Kardiawan, \& Kusuma, 2020). Pembelajaran PJOK bertujuan untuk meningkatkan kebugaran jasmani serta peningkatan kemampuan gerak dasar yang dimiliki siswa (Sugiarto, 2019). Keberhasilan kegiatan pembelajaran dapat diukur dengan keberhasilan siswa dalam memahami materi pembelajaran. Keberhasilan proses pembelajaran PJOK di sekolah dasar dipengaruhi oleh beberapa faktor diantaranya adalah kemampuan guru dalam menyajikan materi pembelajaran, ketersediaan sarana dan sarana penunjang proses pembelajaran, motivasi belajar siswa serta komponen yang tidak dapat dipisahkan adalah media pembelajaran (Angga, Sudarma, \& Suartama, 2020; Nur \& Malik, 2020; Putro, 2016; Safriandono \& Charis, 2014).

Namun, kenyataannya rata-rata guru di sekolah dasar masih banyak yang menggunakan metode konvensional dalam penyampaian materi (Agustini, Kristiantari, \& Putra, 2016). Saat guru menyampaikan materi dengan metode ceramah dalam menyebabkan anak terlihat bosan sehingga anak enggan mengikuti serta memperhatikan pembelajaran di kelas (Supriyono., 2018). Guru belum memanfaatkan teknologi sebagai media pembelajaran karena tidak semua guru mampu menggunakan media berbasis teknologi (Shalikhah, Primadewi, \& Iman, 2018), selain itu jumlah media pembelajaran di SD masih kurang (Andriani, 2016). Guru sebagai salah satu komponen dalam proses pembelajaran harus terampil dalam menggunakan model dan media pembelajaran yang tepat. Tanpa penggunaan model dan media yang jelas, proses pembelajaran menjadi tidak terarah dan tidak menghasilkan hasil yang optimal. Model dan media pembelajaran yang digunakan guru diharapkan mampu mempermudah guru dalam menyampaikan materi sehingga peserta didik dapat menguasai konsep dengan baik (Suranti, Gunawan, \& Sahidu, 2016). Permasalahan yang sering muncul dalam pembelajaran PJOK adalah proses pembelajaran bersifat tradisional. Selain itu permasalahan yang sering terjadi guru mengalami kesulitan dalam menerapkan model pembelajaran PJOK karena dalam setiap materi yang terapkan masih sangat terbatas dan kurangnya literatur terkait media permainan PJOK untuk pembelajaran tematik khususnya pada kelas 1 sekolah dasar. Oleh karena itu guru mengalami kesulitan untuk menemukan dan menggunakan bentuk permainan yang tepat untuk pembelajaran PJOK yang terpadu dengan mata pelajaran lain.

Salah satu solusi yang dibisa dilakukan adalah dengan mengembangkan media pembelajaran video tutorial. Media pembelajaran membawa pesan yang dapat digunakan untuk keperluan pembelajaran dan menyampaikan materi pembelajaran lebih jelas. Media mengandung materi instruksional sehingga merangsang peserta didik untuk belajar. Media pembelajaran membantu guru untuk mempermudah dalam penyampaian materi (Lestari \& Projosantoso, 2016). Video tutorial adalah video yang sengaja dibuat dalam rangka membimbing pembelajaran kepada para siswa atau sekelompok siswa. Media pembelajaran berbasis video ini berpengaruh baik dalam proses pembelajaran karna bisa merangsang ketertarikan siswa untuk memplajari materi yang disampaikan lewat video tersebut (Giana \& Lutfi, 2019). Media pembelajaran berupa video tutorial bermanfaat untuk menunjang suatu proses pembelajaran yang mampu memberikan visualisasi yang baik terhadap mata pelajaran PJOK sehingga siswa semangat dalam mengikuti kegiatan olahraga. Hal ini sejalan dengan hasil penelitian oleh 1) penelitian oleh (Mapicayanti, Jamaludin, \& Fathoni, 2018) menunjukkan bahwa media pembelajaran berbasis video tutorial pada materi mendesain jaringan LAN (Local Area Network) layak digunakan untuk meningkatkan semangat belajar siswa. 2) Penelitian oleh (Giana \& Lutfi, 2019) menyatakan media pembelajaran berbasis video tutorial Layak untuk digunakan sebagai media pembelajaran pada materi tentang Photoshop pada Mata pelajaran dasar desain grafis, 3) penelitian oleh (Batubara \& Batubara, 
2020) menunjukkan hasil bahwa penggunaan video tutorial di masa pandemi virus corona dapat melengkapi sarana pembelajaran daring. Dengan adanya pengembangan media diharapkan dapat membantu tenaga pendidik dalam pengembangan media video permainan khususnya pada pembelajaran PJOK. Suatu proses pembelajaran dikatakan berhasil terlihat dari peserta didik baik dalam sikap, pengetahuan dan keterampilan. Maka dari itu diharapkan pendidik dapat mengembangkan media pembelajaran untuk membantu proses pembelajaran yang lebih baik. Oleh karena itu guru mengalami kesulitan untuk menemukan dan menggunakan bentuk permainan yang tepat untuk pembelajaran PJOK yang terpadu dengan mata pelajaran lain. Guru PJOK menyatakan sangat membutuhkan pengembangan media video permainan untuk materi PJOK pada peserta didik kelas 1 sekolah dasarOleh karena itu guru mengalami kesulitan untuk menemukan dan menggunakan bentuk permainan yang tepat untuk pembelajaran PJOK yang terpadu dengan mata pelajaran lain. Guru PJOK menyatakan sangat membutuhkan pengembangan media video permainan untuk materi PJOK pada peserta didik kelas 1 sekolah dasar. Beberapa temuan penelitian sebelumnya terkait dengan media pembelajaran video tutorial, namun belum ada yang diterapkan pada siswa sekolah dasar untuk mendukung pembelajaran tematik. Kelebihan media ini yaitu siswa akan lebih tertarik belajar dengan gambar dan suara, serta media yang disajikan dengan sederhana sehingga siswa lebih mudah memahami materi . Tujuan dari penelitian ini mengembangkaan media video tutorial untuk mendukung pembelajaran tematik pada kelas 1 sekolah dasar tema 3 kegiatanku". Dengan harapan dapat membantu tenaga pendidik dalam pengembangan media video permainan khususnya pada pembelajaran PJOK berbasis tematik.

\section{METODE}

Jenis penelitian yang digunakan pada penelitian ini adalah penelitian pengembangan. Penelitian pengembangan adalah suatu proses mengembangkan suatu produk baru atau menyempurnakan produk yang telah ada. Dalam produk ini tidak selalu berbentuk buku dan modul tetapi juga bisa berbentuk program pengolahan data pembelajaran di kelas, pembelajaran pelatihan, bimbingan, model-model pendidikan dan yang lainya. Penelitian seperti ini akan terfokus pada tujuan untuk menghasilkan dan mengembangkan produk yang layak digunakan sesuai dengan kebutuhan dalam proses pembelajaran. Pada penelitian pengembangan ini peneliti menggunakan model ADDIE. Penggunaan model ini didasarkan oleh model yang telah disusun secara terstruktur dengan urutan kegiatan yang sistematis dalam memecahkan masalah khusunya pada belajar berkaitan dengan karakteristik dan kebutuhan peserta didik (Mulyatiningsih, 2012).

Metode pengumpulan data dalam penelitian ini menggunakan metode angket atau kuisioner dalam bentuk skala skor. Angket tersebut berisi item-item terkait dengan video tutorial. Instrumen yang berbentuk angket ini digunakan untuk mengumpulkan data hasil rivew dari para ahli yaitu ahli isi mata pelajaran, ahli desain pembelajaran, ahli media pembelajaran dan praktisi lapangan. Data yang dikumpulkan merupakan hasil validitas dari media pembelajaran video tutorial berupa saran dan komentar dari para ahli. Metode analisis data yang digunakan dalam penelitian ini yaitu analisis statistik kualitatif dan kuantitatif. Teknik analisis statistik kualitatif digunakan dalam penelitian ini untuk mengolah data yang berupa komentar, kritikan dan solusi dari hasil review ahli materi dan review ahli media. Sedangkan teknik analisis statistik kuantitatif digunakan untuk mendeskripsikan rata-rata skor dari ahli terkait media yang akan dikembangkan. Teknik analisis data kuantitatif dipilih untuk menganalisis skor yang diperoleh melalui pemberian lembar penilaian media video animasi.

\section{HASIL DAN PEMBAHASAN}

\section{Hasil}

Ahli Isi Materi Pelajaran diberikan kepada dosen prodi pendidikan jasmani kesehatan dan rekreasi atas nama Drs. I Putu Panca Adi, M.Pd. agar mendapat penilaian, tanggapan dan saran. Data yang diperoleh dari hasil uji ahli isi materi terhadap media yang dikembangkan dipaparkan sebagai berikut.

Tabel 1. Uji Ahli Isi Materi

\begin{tabular}{clcc}
\hline No & & Kriteria & Skor \\
\hline 1. & Kejelasan media dan tujuan & 5 \\
2. & Kejelasan indikator & 5 \\
3. & Kejelasan tujuan & 5 \\
4. & Kesesuaian tujuan dan materi & 5 \\
5. & Kejelasan penyajian materi & 5 \\
6. & Kejelasan bahasa yang digunakan & 5 \\
\hline
\end{tabular}




\begin{tabular}{clcc}
\hline No & & Kriteria & Skor \\
\hline 7. & Kemudahan memahami materi & 5 \\
8. & Kejelasan informasi pada ilustrasi gambar & 5 \\
9. & Kecukupan evaluasi & & 4 \\
10. & Kesesuaian evaluasi dan tujuan & Total & 4 \\
\hline & & & 48 \\
\hline
\end{tabular}

Tabel 2. Masukan, Saran dan Komentar

\begin{tabular}{cl}
\hline No & \multicolumn{1}{c}{ Masukan, Saran dan Komentar } \\
\hline 1. & $\begin{array}{l}\text { Informasi pada ilustrasi gambar jangan ditempatkan di tengah-tengah sehingga tidak } \\
\text { mengganggu pemandangan. }\end{array}$ \\
\hline
\end{tabular}

Ahli Media Pembelajaran diberikan kepada dosen jurusan pendidikan teknik informatika atas nama I Nengah Eka Mertayasa, S.Pd., M.Pd. agar mendapat penilaian, tanggapan dan saran. Data yang diperoleh dari hasil uji ahli media pembelajaran terhadap media video yang dikembangkan dipaparkan pada Tabel 3.

Tabel 3. Uji Ahli Media Pembelajaran

\begin{tabular}{|c|c|c|}
\hline No & Kriteria & Skor \\
\hline 1. & Kesesuaian media dan tujuan & 4 \\
\hline 2. & Kesesuaian media dan peserta didik & 5 \\
\hline 3. & Kejelasan tampilan teks & 5 \\
\hline 4. & Nilai penggunaan estetika penggunaan teks secara teks secara keseluruhan & 4 \\
\hline 5. & Kualitas tampilan gambar & 5 \\
\hline 6. & Kesesuaian tata letak teks dan gambar & 5 \\
\hline 7. & Kesesuaian video dengan materi & 5 \\
\hline 8. & Kualitas suara/sound & 5 \\
\hline 9. & Kelancaran video & 5 \\
\hline 10. & Keseimbangan warna & 5 \\
\hline \multirow[t]{2}{*}{11.} & Kesatuan media & 5 \\
\hline & Total & 53 \\
\hline
\end{tabular}

Ahli Desain Pembelajaran diberikan kepada ahli desain pembelajaran dosen jurusan pendidikan teknik informatika atas nama I Gede Bendesa Subawa, S.Pd., M. Kom. Data yang diperoleh dari hasil uji ahli desain pembelajaran terhadap media video tutorial model permainan PJOK untuk mendukung pembelajaran tematik dijabarkan pada Tabel 4.

Tabel 4. Uji Ahli Desain Pembelajaran

\begin{tabular}{|c|c|c|}
\hline No & Kriteria & Skor \\
\hline 1. & Kemenarikan tampilan video & 5 \\
\hline 2. & Keseimbangan tata warna & 5 \\
\hline 3. & Ketetapan penggunaan desain penyajian materi & 5 \\
\hline 4. & Kejelasan paparan materi & 5 \\
\hline 5. & Kesesuaian huruf yang digunakan & 5 \\
\hline 6. & Kesesuaian tata letak teks dengan gambar & 4 \\
\hline 7. & Konsisten dengan tujuan pembelajaran & 5 \\
\hline \multirow[t]{2}{*}{8.} & Kesesuaian penempatan komponen video & 4 \\
\hline & Total & 38 \\
\hline
\end{tabular}

Tabel 5. Masukan, Saran dan Komentar

\begin{tabular}{cl}
\hline No & Masukan, Saran dan Komentar \\
\hline 1. & Intro video sebaiknya dimulai dengan judul. \\
\hline
\end{tabular}

Ahli Praktisi Lapangan diberikan kepada ahli praktisi lapangan yaitu guru sekolah dasar yang berlatar belakang pendidikan PJOK di SD Negeri 4 Tegal Linggah atas nama I Gede Nova Karsawan, S.Pd. Data yang diperoleh dari hasil uji ahli praktisi lapangan terhadap media video tutorial model permainan PJOK untuk mendukung pembelajaran tematik dijabarkan sebagai berikut. 
Tabel 6. Uji Ahli Praktisi Lapangan

\begin{tabular}{|c|c|c|}
\hline No & Aspek Penilaian & Kriteria Penilaian \\
\hline \multicolumn{3}{|c|}{ TAMPILAN } \\
\hline 1. & Video permainan terlihat menarik & 5 \\
\hline 2. & Tampilan video terlihat jelas & 5 \\
\hline 3. & Tulisan pada video mudah terbaca & 4 \\
\hline 4. & Perpaduan antara tulisan dan video sesuai & 5 \\
\hline 5. & Kualitas suara/Sound & 5 \\
\hline \multicolumn{3}{|c|}{ RELEVANSI } \\
\hline 6. & $\begin{array}{l}\text { Permainan sesuai dengan kompetensi yang harus dikuasai peserta } \\
\text { didik }\end{array}$ & 5 \\
\hline 7. & $\begin{array}{l}\text { Tugas gerak yang diberikan relevan dengan kompetensi yang harus } \\
\text { dikuasai peserta didik }\end{array}$ & 5 \\
\hline 8. & $\begin{array}{l}\text { Permainan seseuai dengan karakteristik pertumbuhan dan } \\
\text { perkembangan peserta didik }\end{array}$ & 5 \\
\hline 9. & $\begin{array}{l}\text { Permainan yang dirancang singkat dan mudah dipahami oleh } \\
\text { peserta didik }\end{array}$ & 4 \\
\hline 10. & Permainan yang dirancang mampu dilaksanakan oleh peserta didik & 5 \\
\hline 11. & Peraturan permainan mudah dipahami & 4 \\
\hline 12. & $\begin{array}{l}\text { Sarana dan prasarana yang digunakan dalam permainan mudah } \\
\text { didapat dana man bagi keselamatan peserta didik }\end{array}$ & 5 \\
\hline \multicolumn{3}{|c|}{ KESESUAIAN DENGAN TUNTUTAN PEMBELAJARAN } \\
\hline 13. & Mendorong rasa ingin tahu peserta didik & 5 \\
\hline 14. & Memotivasi peserta didik untuk aktif bergerak & 5 \\
\hline 15. & $\begin{array}{l}\text { Mendorong perkembangan aspek pengetahuan, sikap dan } \\
\text { keterampilan }\end{array}$ & 5 \\
\hline 16. & Mendorong terjadinya interaksi dengan lingkungannya & 4 \\
\hline \multirow[t]{2}{*}{17.} & $\begin{array}{l}\text { Permainan mengiinternalisasikan dengan karakter bangsa } \\
\text { Indonesia }\end{array}$ & 4 \\
\hline & Total & 80 \\
\hline
\end{tabular}

Tabel 7. Masukan, Saran Komentar

\begin{tabular}{cl}
\hline No & \multicolumn{1}{c}{ Masukan, Saran dan Komentar } \\
\hline 1. & Video pertama diperkenalkan nama pembelajarannya, tema dan sub tema \\
2. & Tulisan bisa diperjelas lagi agar lebih mudah di baca \\
3. & Manfaat atau tujuan jelas \\
4. & Saat kegiatan jika sendiri memantulkan di tembok diperlihatkan atau kegiatannya dihilangkan \\
5. & Kegiatan atau peraturannya dijelaskan setelah video kegiatannya jelas \\
6. & Penutup isi share link youtube untuk like and koment. Untuk pengembangan video \\
\hline
\end{tabular}

Penilaian yang pertama dilakukan oleh ahli isi materi mendapatkan kategori sangat baik dengan presentase 96\%. Presentase tersebut diperoleh dari kejelasan media dan tujuan, kejelasan indikator, kejelasan tujuan, kesesuaian tujuan dengan materi, kejelasan penyajian materi, kejelasan bahasa yang digunakan, kemudahan memahami materi, kejelasan informasi pada ilustari gambar, kecukupan evaluasi, kesesuaian evaluasi dan tujuan. Walapun presentase menyatakan sangat baik tetapi media ini memiliki masukan, saran dan komentar dari ahli isi materi. Adapun masukan, saran dan komentar sebagai berikut: informasi pada ilustrasi gambar jangan ditempatkan di tengah-tengah sehingga tidak mengganggu pemandangan.

Penilaian kedua dilakukan oleh ahli media pembelajaran mendapatkan kriteria sangat baik dengan presentase 96\%. Presentase tersebut diperoleh dari kesesuaian media dan tujuan, kesesuaian media dengan peserta didik, kejelasan tampilan teks, nilai penggunaan estetika dan penggunaan teks secara keseluruhan, kualitas tampilan gambar, kesesuaian tata letak teks dan gambar, kesesuaian video dengan materi, kualitas suara/sound, kelancaran video, keseimbangan warna dan kesatuan media. Tidak ada masukan, saran maupun komentar dari ahli media karena menurut beliau media video tutorial model permainan PJOK untuk mendukung pembelajaran tematik pada kelas 1 sekolah dasar dikatakan sangat bagus dan sudah layak digunakan untuk proses pembelajaran. 
Penilaian oleh ahli desain pembelajaran mendapatkan presentase 95\% dengan kategori sangat baik. Penilaian tersebut diperoleh dari kemenarikan tampilan video, keseimbangan tata warna, ketetapan penggunaan desain penyajian materi, kejelasan paparan materi, kesesuaian huruf yang digunakan, kesesuaian tata letak teks dengan gambar, konsisten dengan tujuan pembelajaran, kesesuaian penempatan komponen video. Adapun masukan, saran dan komentar: intro video sebaiknya dimulai dengan judul. Penilaian yang terakhir oleh ahli praktisi lapangan media video tutorial model permainan PJOK untuk mendukung pembelajaran tematik pada kelas 1 sekolah dasar ini mendapatkan presentase 94\% dengan kategori sangat baik.

\section{Pembahasan}

Berdasarkan hasil yang ditemukan maka disimpulkan bahwa pengembangan video tutorial model permainan dalam pjok untuk mendukung pembelajaran tematik tema 3 kegiatanku dinyatakan valid dan layak digunakan hal ini disebabkan oleh beberapa faktor yaitu sebagai berikut: video permainan terlihat menarik, tampilan video terlihat jelas, tulisan pada video mudah terbaca, perpaduan antara tulisan dan video sesuai, kualitas suara/sound, permainan sesuai dengan kompetensi yang harus dikuasai peserta didik, tugas gerak yang diberikan relevan dengan kompetensi yang harus dikuasai peserta didik, permainan sesuai dengan karakteristik pertumbuhan dan perkembangan peserta didik, permainan yang dirancang singkat dan mudah dipahami oleh peserta didik, permainan yang dirancang mampu dilaksanakan oleh peserta didik, permainan yang dirancang mampu dilaksanakan oleh peserta didik, peraturan permainan mudah dipahami, sarana dan prasarana yang digunakan dalam permainan mudah didapat dana man bagi keselamatan peserta didik, mendorong rasa ingin tahu peserta didik, memotivasi peserta didik untuk aktif bergerak, mendorong perkembangan aspek pengetahuan, sikap dan keterampilan, mendorong terjadinya interaksi dengan lingkungannya, permainan mengiinternalisasikan dengan karakter bangsa Indonesia (Amirullah \& Hardinata, 2017; Yamin, 2020). Yang artinya Media yang dikembangkan disesuaikan dengan kebutuhan anak SD khususnya siswa kelas 1. Penggunaan media dalam proses pembelajaran sangat penting, karena dengan bantuan media siswa dapat melhat langsung contohnya tanpa perlu membayangkannya (Diputra, 2016; Siddiq, Sudarma, \& Simamora, 2020).

Kedua, media pembelajaran video tutorial layak digunakan karena mempermudah dan membantu guru dalam memnyampaikan materi pembelajaran dan mempermudah siswa memahami materi pembelajaran beserta dapat menarik perhatian dan minat siswa. Penggunaan media pembelajaran yang tepat dalam kegiatan pembelajaran akan menciptakan suasana efektif dan efisien sehingga memberikan dampak pada pemahaman siswa (Saputra, A., \& Filahanasari, 2020). Media pembelajaran video tutorial adalah salah media yang dapat digunakan untuk mempermudah proses pembelajaran. Media video totorial adalah bahan pengajaran yang digunakan oleh guru untuk membatu siswa memahami materi yang diberikan lewat tayangan rangkaian gambar hidup dan pesan-pesan (Erni \& Farihah, 2021). Keunggulan video tutorial dibandingkan dengan media pembelajaran lainnya adalah sebagai berikut:1) Video tutorial sangat jelas dalam mendemonstrasikan suatu fenomena dan prosedur yang melibat suatu gerakan 2) Pengguna video tutorial dapat mempercepat dan memperlambat gerakan video tutorial sehingga materi yang disajikan lebih jelas, 3) Video tutorial dapat memanfaatkan animasi untuk mengilustrasikan materi yang abstrak dan bergerak, 4) Video tutorial dapat menarik perhatian dan minat siswa melalui media gambar bergerak, audio, dan teks, 5) Mahasiswa sebagai pengguna smartphone cukup mudah dalam menggunakan video tutorial, dan 6) Video tutorial dapat menggantikan kegiatan studi lapangan (Prastowo, 2018).

Sehingga pengembangan video tutorial model permainan sangat membantu guru khususnya guru PJOK karena dengan media video, minat siswa untuk belajar kan tumbuh. Apalagi disertai dengan video tutorial gerakan yang terasa susah dilakukan dalam pelajaran olahraga akan lebih mudah untuk siswa pelajari karena ada langkah-langkah yang di demonstrasikan. Hasil penelitian ini sejalan dengan penelitian sebelumnya yang menunjukkan bahwa penggunaan media video dalam pembelajaran dapat meningkatan hasil belajar siswa (Parastri, 2021; Prabawa \& Restami, 2020; Sabban \& Hayun, 2018). Pengembangan media video pembelajaran yang dilaksanakn dengan baik akan mampu meningkatkan pemahaman siswa dalam belajar (Hidayati, Adi, \& Praherdhiono, 2019; Krissandi, 2018; Ponza, Jampel, \& Sudarma, 2018). Sehingga kedepannya diharapkan guru guru sebagai salah satu faktor keberhasilan pendidikan dapat mengembangkan dan menggunakan media pembelajaran yang tepat dalam proses pembelajarannya.

\section{SIMPULAN DAN SARAN}

Pengembangan media video totorial dikembangkan secara bertahap menggunakan tahapan ADDIE serta dari analisis data validasi media video toturial permainan diperoleh penilaian yang sudah 
dinilai oleh dosen ahli tersebut memperoleh validitas sangat baik. Sehingga pengembangan produk multimedia berbasis video tutorial model permainan dalam PJOK sangat layak digunakan untuk untuk mendukung pembelajaran tematik Tema 3 Kegiatanku pada kelas 1 sekolah dasar. Diharapkan dengan adanya media video ini pembelajaran menjadi lebih efektif dan efisien, sehingga tujuan pembelajaran PJOK dapat tercapai.

\section{DAFTAR RUJUKAN}

Agustini, P. P., Kristiantari, M. . R., \& Putra, D. K. N. S. (2016). Penerapan Model Pembelajaran Berbasis Masalah Berbantuan Media Audio Visual Untuk Meningkatkan Hasil Belajar Keterampilan Menyimak Tema Sejarah Peradaban Indonesia Pada Siswa Kelas V Sdn 8 Sumerta. MIMBAR PGSD Undiksha, 4(1). Https://Doi.Org/10.23887/Jjpgsd.V4i1.7265.

Amirullah, G., \& Hardinata, R. (2017). Pengembangan Mobile Learning Bagi Pembelajaran. JKKP (Jurnal Kesejahteraan Keluarga Dan Pendidikan), 4(02), 97-101. Https://Doi.Org/Https://Doi.Org/10.21009/JKKP.042.07.

Andriani, S. (2016). Pengaruh Motivasi Belajar Dan Penggunaan Media Pembelajaran Terhadap Hasil Belajar IPS Siswa Kelas IV Di SDN Mayangan 6 Kota Probolinggo. Jurnal Penelitian Dan Pendidikan IPS, 10(1), 101-118.

Angga, P. M. W., Sudarma, I. K., \& Suartama, I. K. (2020). E-Komik Pendidikan Untuk Membentuk Karakter Dan Meningkatkan Hasil Belajar Siswa Kelas V Pada Mata Pelajaran Bahasa Indonesia. Jurnal EDUTECH Universitas Pendidikan Ganesha., 8(2), . 93-106. Https://Doi.Org/10.23887/Jeu.V8i2.28920.

Batubara, H. H., \& Batubara, D. S. (2020). Penggunaan Video Tutorial Untuk Mendukung Pembelajaran Daring Di Masa Pandemi Virus Corona. MUALLIMUNA : JURNAL MADRASAH IBTIDAIYAH, 5(2), 7484. Https://Doi.Org/10.31602/Muallimuna.V5i2.2950.

Cintamulya, I. (2015). Peranan Pendidikan Dalam Memepersiapkan Sumber Daya Manusia Di Era Informasi Dan Pengetahuan. Formatif: Jurnal Ilmiah Pendidikan MIPA, 2(2). Https://Doi.Org/10.30998/Formatif.V2i2.89.

Diputra, K. S. (2016). Pengembangan Multimedia Pembelajaran Tematik Integratif Untuk Siswa Kelas Iv Sekolah Dasar. JPI (Jurnal Pendidikan Indonesia), 5(2), 125. Https://Doi.Org/10.23887/JpiUndiksha.V5i2.8475.

Erni, E., \& Farihah, F. (2021). Pengembangan Media Video Tutorial Pada Mata Kuliah Teknologi Menjahit Dalam Mendukung Pembelajaran Dimasa Pandemi Covid-19. Jurnal Pendidikan Teknologi Dan Kejuruan, 18(1), 121-131. Https://Doi.Org/10.23887/Jptk-Undiksha.V18i1.30397.

Fadillah, A., \& Bilda, W. (2019). Pengembangan Video Pembelajaran Matematika Berbatuan Aplikasi Sparkoll Videoscribe. Jurnal Gantang, 4(2), 177-182. Https://Doi.Org/10.31629/Jg.V4i2.1369.

Giana, G. J., \& Lutfi, S. (2019). Pengembangan Media Pembelajaran Berbasis Video Tutorial Mata Pelajaran Dasar Desain Grafis Pada Kelas X Multimedia Di SMK Negeri 1 Sakra. EDUMATIC: Jurnal Pendidikan Informatika, 3(1), 20-29. Https://Doi.Org/10.29408/Edumatic.V3i1.1390.

Gurung, R. A. R. (2020). Call It Out: Recognizing Good Teaching And Learning. Journal Of Applied Research In Memory And Cognition, 9(2), 161-164. Https://Doi.Org/10.1016/J.Jarmac.2020.02.003.

Haris, I. N. (2018). Model Pembelajaran Peer Teaching Dalam Pembelajaran Pendidikan Jasmani. Journal Of Chemical Information And Modeling, 4(9), 2.

Henriksen, D., Richardson, C., \& Shack, K. (2020). Mindfulness And Creativity: Implications For Thinking And Learning. Thinking Skills And Creativity, 37(December 2019), 100689. Https://Doi.Org/10.1016/J.Tsc.2020.100689.

Hidayah, N., Pgmi, J., Tarbiyah, F., \& Keguruan, D. (2015). Tematik Sd. TERAMPIL Pendidikan Dan Pembelajaran Dasar, 2, 34-49.

Hidayati, A., Adi, E., \& Praherdhiono, H. (2019). Bangan Media Video Pembelajaran Untuk Meningkatkan Pemahaman Materi Gaya Kelas Iv Di Sdn Sukoiber 1 Jombang. JINOTEP (Jurnal Inovasi Dan Teknologi Pembelajaran) Kajian Dan Riset Dalam Teknologi Pembelajaran, 6(1), 45-50. Https://Doi.Org/10.17977/Um031v6i12019p045.

Idris, I., \& Sida, S. C. (2019). Pengaruh Model Problem Based Learning Terhadap Keterampilan Proses Dan Hasil Belajar IPS Siswa SD. Indonesian Journal Of Primary Education, 3(2), 58-63.

Krissandi, A. D. S. (2018). Pengembangan Video Tematik Sebagai Pengantar Pembelajaran Kurikulum 2013 Di Sekolah Dasar. Premiere Educandum : Jurnal Pendidikan Dasar Dan Pembelajaran, 8(1), 68. Https://Doi.Org/10.25273/Pe.V8i1.2233.

Lestari, D. I., \& Projosantoso, A. K. (2016). Pengembangan Media Komik IPA Model PBL Untuk Meningkatkan Kemampuan Berfikir Analitis Dan Sikap Ilmiah Developing Science Comic Media 
Using The Problem-Based Learning Model To Increase The Analytical Thinking Ability And Scientific Attitude. Jurnal Inovasi Pendidikan IPA, 2(2), 145-155. Https://Doi.Org/10.21831/Jipi.V2i2.7280.

Mapicayanti, D., Jamaludin, J., \& Fathoni, A. (2018). Perancangan Media Pembelajaran Berbasis Video Tutorial Mendesain Jaringan Lokal/LAN Kelas X TKJ. Edumatic: Jurnal Pendidikan Informatika, 2(2). Https://Doi.Org/10.29408/Edumatic.V2i2.913.

Mulyatiningsih, E. (2012). Metode Penelitian Terapan Bidang Pendidikan (Apri Nuryanto, Ed.). Bandung: ALFABETA.

Nada, I., Utaminingsih, S., \& Ardianti, S. D. (2018). Penerapan Model Open Ended Problems Berbantuan Cd Pembelajaran Untuk Meningkatkan Kemampuan Berpikir Kreatif Siswa Kelas Iv Sd 1 Golantepus. Jurnal Pendidikan Sekolah Dasar, 4(2), 216. Https://Doi.Org/10.30870/Jpsd.V4i2.3856.

Nur, L., \& Malik, A. A. (2020). Motivasi Belajar Pendidikan Jasmani: Penerapan Teknik Memotivasi Teaching By Invitation Pada Pendekatan Teknis. Journal of Teaching Physical Education In Elementary School, 3(2), 31-36.

Pambudi, M. I., Winarno, M., \& Dwiyogo, W. D. (2019). Perencanaan Dan Pelaksanaan Pembelajaran Pendidikan Jasmani Olahraga Kesehatan. Jurnal Pendidikan Olahraga, Universitas Negeri Malang, 4(1), 110-116.

Pane, A., \& Dasopang, M. D. (2017). Belajar Dan Pembelajaran. FITRAH Jurnal Kajian Ilmu-Ilmu Keislaman, 3(2), 333-352. Retrieved Hom Http://Jurnal.IainPadangsidimpuan.Ac.Id/Index.Php/F/Article/View/945/795.

Parastri, R. W. (2021). Pengembangan Media Pembelajaran Video Animasi Berbasis Sparkol Videoscribe Pada Mata Pelajaran Penataan Produk Kelas Xii Bdp Di Smk Negeri 1 Boyolangu Tulungagung. Jurnal Pendidikan Tata Niaga (JPTN), 9(3), 1328-1334.

Ponza, P. J. R., Jampel, I. N., \& Sudarma, I. K. (2018). Pengembangan Media Video Animasi Pada Pembelajaran Siswa Kelas IV Di Sekolah Dasar. Jurnal Edutech Undiksha, 6(1), 9-19.

Prabawa, D. G. A. P., \& Restami, M. P. (2020). Pengembangan Multimedia Tematik Berpendekatan Saintifik Untuk Siswa Sekolah Dasar. Mimbar PGSD Undikhsa, 8(3), 479-491.

Prastowo. (2018). Sumber Belajar Dan Pusat Sumber Belajar. Jakarta: Prenadamedia Group.

Putro, B. S. (2016). Faktor- Faktor Pendukung Keterlaksanaan Pembelajaran Pjok Materi Beladiri Di Slta Se-Kecamatan Sragen. Pendidikan Jasmani Kesehatan Dan Rekreasi, 5(11).

Raibowo, S., \& Nopiyanto, Y. E. (2020). Evaluasi Pembelajaran Pendidikan Jasmani Olahraga \& Kesehatan Pada SMP Negeri Se-Kabupaten Mukomuko Melalui Pendekatan Model Context, Input, Process \& Product ( CIPP ). Jurnal Pendidikan Kesehatan Rekreasi, 6(2), 146-165. Https://Doi.Org/10.5281/Zenodo.3881891.

Sabban, I., \& Hayun, S. (2018). Jurnal Mitra Pendidikan ( JMP Online ). Jurnal Mitra Pendidikan, 2(1), 1122.

Safriandono, A. N., \& Charis, M. (2014). Rancang Bangun E-Lembar Kerja Siswa Sebagai Media Pembelajaran Yang Praktis, Fleksibel Dan Edukatif Berbasis Web. Jurnal Teknik-UNISFAT, 10(1), 25-35.

Saputra, A., \& Filahanasari, E. (2020). Pengembangan Media Video Untuk Pengenalan Karir Di Taman Kanak-Kanak. Jurnal Pedagogi Dan Pembelajaran. Jurnal Pedagogi Dan Pembelajaran, Vol. 3, No, 499-507. Https://Doi.Org/Doi: Http://Dx.Doi.Org/10.23887/Jp2.V3i3.29110.

Satyawan, I. M., Kardiawan, I. K. H., \& Kusuma, K. C. A. (2020). Studi Kelayakan Pembentukan Program Studi Pendidikan Jasmani Pendidikan Guru Sekolah Dasar (PJ PGSD) Tahun 2019. Jurnal IKA, 18(1), 73-84. Https://Doi.Org/10.23887/Ika.V18i1.28385.

Setiawan, A., \& Rahmat, A. (2018). Pengaruh Pembelajaran Bola Tangan Terhadap Perilaku Sosial Siswa. Jurnal Pendidikan Jasmani Dan Olahraga. Https://Doi.Org/Https://Doi.Org/10.17509/ Jpjo.V3i1.10188.

Shalikhah, N. D., Primadewi, A., \& Iman, M. S. (2018). Media Pembelajaran Interaktif Berbantu Software $\begin{array}{lllll}\text { Lectora Inspire. Desimal: Jurnal Matematika, } 237 . & \text { 1(2), }\end{array}$ Https://Doi.Org/10.24042/Djm.V1i2.2583.

Siddiq, Y. I., Sudarma, I. K., \& Simamora, A. H. (2020). Pengembangan Animasi Dua Dimensi Pada Pembelajaran Tematik Untuk Siswa Kelas III Sekolah Dasar. Jurnal Edutech Undiksha, 8(2), 49. Https://Doi.Org/10.23887/Jeu.V8i2.28928.

Spyanawati, L. ., \& Lesmana, I. K. Y. . (2016). Pengaruh Model Dan Media Pembelajaran Terhadap Hasil Belajar Kemampuan Dasar Senam Lantai Pada Mahasiswa Jurusan Penjaskesrek Undiksha. JPI (Jurnal Pendidikan Indonesia), 5(1), 97. Https://Doi.Org/10.23887/Jpi-Undiksha.V5i1.8932.

Suadnyana, I. N., Wiyasa, I. K. N., Ardana, I. K., Putra, D. K. N. S., \& Wulandari, I. G. A. A. (2017). Pelatihan Penyusunan Rpp Tematik Integratif Menggunakan Pendekatan Saintifik Bagi Guru-Guru Sekolah 
Dasar Gugus VIII Abiansemal Badung Tahun Pelajaran 2015/2016. International Journal Of Community Service Learning, 1(1), 63- 66. Https://Doi.Org/10.23887/Ijcsl.V1i1.11908.

Sugiarto, B. G. (2019). Pelaksanaan Kegiatan Belajar Mengajar Pendidikan Jasmani Di Sekolah Dasar Inklusi. Halaman Olahraga Nusantara (Jurnal Ilmu Keolahragaan), 2(2), 105. Https://Doi.Org/10.31851/Hon.V2i2.3011.

Suprianingsih, N. W. S., \& Wulandari, I. G. (2020). Model Problem Posing Berbantuan Media Question Box Berpengaruh Terhadap Kompetensi Pengetahuan Matematika Siswa SD. Jurnal Mimbar Ilmu, 25(3), 308-318. Https://Doi.Org/10.23887/Mi.V25i3.25472.

Supriyono. (2018). Pentingnya Media Pembelajaran Untuk Meningkatkan Minat Belajar Siswa SD. Edustream: Jurnal Pendidikan Dasar, II(1), 43-48. Retrieved From Journal.Unesa.Ac.Id/Index.Php/Jpd/Article/View/6262/3180.

Suranti, N. M. Y., Gunawan, \& Sahidu, H. (2016). Pengaruh Model Project Based Learning Berbantuan Media Virtual Terhadap Penguasaan Konsep Peserta Didik Pada Materi Alat-Alat Optik. Jurnal Pendidikan Fisika Dan Teknologi, 2(2), 73-79. Https://Doi.Org/10.29303/Jpft.V2i2.292.

Yamin, A. (2020). Pengembangan Media Pembelajaran Berbasis Aplikasi Android Materi Integrasi Nasional Dalam Bingkai Bhinneka Tunggal Ika Bagi Siswa Kelas X SMAN 1 Puri Mojokerto. Kajian Moral Dan Kewarganegaraan, 8(2). 